\title{
National Antimicrobial Resistance Monitoring System: Two Decades of Advancing Public Health Through Integrated Surveillance of Antimicrobial Resistance
}

\author{
Beth E. Karp,, Heather Tate, Jodie R. Plumblee, ${ }^{3}$ Uday Dessai, Jean M. Whichard, ${ }^{4}$ Eileen L. Thacker, ${ }^{3}$ \\ Kis Robertson Hale, Wanda Wilson, ${ }^{4}$ Cindy R. Friedman, ${ }^{1}$ Patricia M. Griffin, ${ }^{1}$ and Patrick F. McDermott ${ }^{2}$
}

\begin{abstract}
Drug-resistant bacterial infections pose a serious and growing public health threat globally. In this review, we describe the role of the National Antimicrobial Resistance Monitoring System (NARMS) in providing data that help address the resistance problem and show how such a program can have broad positive impacts on public health. NARMS was formed two decades ago to help assess the consequences to human health arising from the use of antimicrobial drugs in food animal production in the United States. A collaboration among the Centers for Disease Control and Prevention, the U.S. Food and Drug Administration, the United States Department of Agriculture, and state and local health departments, NARMS uses an integrated "One Health" approach to monitor antimicrobial resistance in enteric bacteria from humans, retail meat, and food animals. NARMS has adapted to changing needs and threats by expanding surveillance catchment areas, examining new isolate sources, adding bacteria, adjusting sampling schemes, and modifying antimicrobial agents tested. NARMS data are not only essential for ensuring that antimicrobial drugs approved for food animals are used in ways that are safe for human health but they also help address broader food safety priorities. NARMS surveillance, applied research studies, and outbreak isolate testing provide data on the emergence of drug-resistant enteric bacteria; genetic mechanisms underlying resistance; movement of bacterial populations among humans, food, and food animals; and sources and outcomes of resistant and susceptible infections. These data can be used to guide and evaluate the impact of science-based policies, regulatory actions, antimicrobial stewardship initiatives, and other public health efforts aimed at preserving drug effectiveness, improving patient outcomes, and preventing infections. Many improvements have been made to NARMS over time and the program will continue to adapt to address emerging resistance threats, changes in clinical diagnostic practices, and new technologies, such as whole genome sequencing.
\end{abstract}

Keywords: antimicrobial resistance, public health, surveillance, foodborne disease, NARMS, One Health

\section{Introduction}

D RUG-RESISTANT BACTERIAL infections pose a serious and growing public health threat globally. In the United States, they are estimated to cause more than 2 million illnesses and 23,000 deaths each year. The Centers for Disease Control and Prevention (CDC) estimates that more than 400,000 of these illnesses are caused by drug-resistant nontyphoidal Salmonella and Campylobacter, zoonotic enteric pathogens that are transmitted commonly through food (CDC, 2013).

Antimicrobial use is the single most important factor driving increases in antimicrobial resistance (CDC, 2013). Vital to the health of humans and animals, antimicrobial drugs are used for treatment and sometimes prophylaxis of

\footnotetext{
${ }^{1}$ Division of Foodborne, Waterborne, and Environmental Diseases, Centers for Disease Control and Prevention, Atlanta, Georgia.

${ }^{2}$ Office of Research, Center for Veterinary Medicine, U.S. Food and Drug Administration, Laurel, Maryland.

${ }^{3}$ Agricultural Research Service, United States Department of Agriculture, Athens, Georgia.

${ }^{4}$ Food Safety and Inspection Service, United States Department of Agriculture, Washington, District of Columbia.
}

(C) Beth E. Karp et al. 2017; Published by Mary Ann Liebert, Inc. This is an Open Access article distributed under the terms of the Creative Commons Attribution License, which permits unrestricted use, distribution, and reproduction in any medium, provided the original work is properly cited. Mary Ann Liebert, Inc. offers reprint services for those who want to order professionally produced copies of articles published under the Creative Commons Attribution (CC BY) license. To obtain a price quote, email Reprints@liebertpub.com. Please include the article's title or DOI, quantity, and delivery destination in your email. 
bacterial infections. In agricultural settings, they are used to prevent, control, and treat infections, as well as to enhance growth and feed efficiency in herds and flocks of animals raised for food (Gilbert et al., 2007). Antimicrobial use selects for drug-resistant bacteria, which can spread among and between humans and animals and disseminate through contaminated food, water, and environments (Marshall and Levy, 2011; Finley et al., 2013). Monitoring antimicrobial resistance is critical for identifying emerging resistance and for developing and assessing the effectiveness of mitigation strategies (WHO, 2012, 2013; CDC, 2013).

The National Antimicrobial Resistance Monitoring System (NARMS) monitors antimicrobial resistance in bacteria transmitted commonly through food in the United States. In this review, we describe the role of NARMS in providing data that help address the resistance problem and show how such a program can have broad positive impacts on public health that extend beyond resistance surveillance and research.

\section{NARMS Is Designed for Public Health}

NARMS was established in 1996 after an expert panel convened by the U.S. Food and Drug Administration (FDA) in 1994 recommended establishing a national surveillance system to monitor resistance among selected enteric bacteria of animals that can cause disease in humans (FDA, 1994a, 1994b, 2000). NARMS is a collaborative effort of three federal agencies, CDC, FDA, and the United States Department of Agriculture (USDA), as well as state and local health departments in all 50 states. It is designed to help assess the consequences to human health arising from the use of antimicrobial drugs in food animal production with a view toward mitigation. Table 1 summarizes core NARMS activities along with key contributions and impacts of the program.

The main goals of NARMS are to:

(1) Monitor trends in antimicrobial resistance among enteric bacteria from humans, retail meats, and animals;

(2) Disseminate timely information on antimicrobial resistance in pathogenic and commensal organisms to stakeholders in the United States and abroad to promote interventions that reduce resistance among foodborne bacteria;

(3) Conduct research to better understand the emergence, persistence, and spread of antimicrobial resistance; and

(4) Provide data that assist the FDA in making decisions related to the approval of safe and effective antimicrobial drugs for animals (FDA, 2012a).

NARMS advances food safety and public health in various ways. NARMS provides data on the emergence of drugresistant enteric bacteria; movement of bacterial populations among humans, food animals, and other sources; genetic mechanisms underlying resistance; and risk factors for and outcomes of resistant infections. These data are essential for ensuring that antimicrobial drugs approved for food animals are used in ways that are safe for human health and for implementing and evaluating the impact of interventions designed to limit the spread of resistance. They also guide antimicrobial stewardship efforts aimed at preserving drug effectiveness and improving patient outcomes and they inform estimates of the burden of illness which may be used for allocating resources.
Although NARMS is focused on resistance, data from the program also help address broader food safety priorities. NARMS provides data on the prevalence of pathogens in food categories under surveillance, types of strains predominant in different foods, and shifts in serotypes among Salmonella isolates from food and animals over time. NARMS Salmonella isolates from food and animals are subtyped using pulsed-field gel electrophoresis (PFGE). To assist with outbreak investigations, PFGE patterns of those isolates are uploaded to PulseNet, the molecular subtyping network for foodborne disease surveillance. NARMS also has a network of experts and a sampling and testing program that can serve as a platform for targeted studies to characterize emerging microbial hazards in food and food animals.

\section{Monitoring Resistance Using an Integrated "One Health" Approach}

\section{One Health approach}

The One Health concept is based on the recognition that the health of people, animals, and the environment are interconnected and that a collaborative approach is needed to ensure optimal health for each (Lammie and Hughes, 2016). Because antimicrobial resistance is a complex and multifaceted problem that affects humans, animals, and the environment, detecting and controlling it requires a holistic and integrated "One Health" approach (White House, 2014a, 2015; WHO/FAO/OIE, 2015; Lammie and Hughes, 2016). Consistent with this approach, the World Health Organization (WHO) recommends integrated surveillance of resistance in foodborne bacteria, which is described as "the coordinated sampling and testing of bacteria from food animals, foods, and clinically ill humans, and the subsequent evaluation of antimicrobial resistance trends throughout the food production and supply chain using harmonized methods" (WHO, 2013). The NARMS program uses such an approach to surveillance, advancing both food safety and animal health by serving as an important tool in the decision-making process for antimicrobial drug approval and use in food animals.

\section{NARMS surveillance}

NARMS surveillance focuses on two major zoonotic bacterial causes of foodborne illness in the United States, nontyphoidal Salmonella and Campylobacter. Food animal and retail meat surveillance also include Enterococcus and Escherichia coli, common intestinal bacteria that can serve as reservoirs of resistance genes and indicators of selection pressures in Gram-positive and Gram-negative bacteria, respectively (WHO, 2013). In addition, CDC uses the NARMS human surveillance platform for monitoring resistance in E. coli O157, Vibrio, and the nonzoonotic enteric pathogens, Shigella and typhoidal Salmonella. Long-standing collaborations among epidemiologists, microbiologists, and others from public health and agriculture agencies have been essential for the program's effectiveness.

The main components of NARMS surveillance are summarized in this section and in Table 2. NARMS has adapted to changing needs and threats by expanding the catchment areas for surveillance, examining new isolate sources, adding bacteria under surveillance, adjusting sampling schemes, and modifying antimicrobial agents tested over the years. More detailed descriptions of NARMS sampling and testing 
Table 1. Major Activities, Contributions, and Impact of the National Antimicrobial Resistance Monitoring System

\begin{tabular}{|c|c|c|}
\hline NARMS activities & $\begin{array}{c}\text { Contributions of NARMS program } \\
\text { and scientists }\end{array}$ & Examples of impact \\
\hline $\begin{array}{l}\text { Surveillance of } \\
\text { resistance }\end{array}$ & $\begin{array}{l}\text { - Collects and cultures retail meat and } \\
\text { animal samples } \\
\text { - Performs antimicrobial susceptibility test- } \\
\text { ing for isolates from humans, retail meats, } \\
\text { and food animals } \\
\text { - Detects emerging resistance threats and } \\
\text { monitors resistance trends } \\
\text { - Provides data for policy and regulatory } \\
\text { actions, risk assessments, burden of illness } \\
\text { estimates, and research }\end{array}$ & $\begin{array}{l}\text { Detected emerging resistance in Campylobacter } \\
\text { (fluoroquinolones), nontyphoidal Salmonella } \\
\text { (cephalosporins), and Shigella (azithromycin) } \\
\text { - Provided data for a quantitative risk assessment } \\
\text { on the human health impact of resistant Campylo- } \\
\text { bacter in chicken } \\
\text { - Provided data to estimate the number of resistant } \\
\text { Salmonella and Campylobacter infections in } \\
\text { humans } \\
\text { - Provided data to support withdrawing approvals for } \\
\text { fluoroquinolone drugs for poultry and prohibiting } \\
\text { certain extralabel uses of cephalosporins in food } \\
\text { animals }\end{array}$ \\
\hline $\begin{array}{l}\text { Outbreak isolate } \\
\text { testing and } \\
\text { investigation }\end{array}$ & $\begin{array}{l}\text { - Conducts and rapidly reports results of } \\
\text { antimicrobial susceptibility testing of out- } \\
\text { break isolates } \\
\text { - Provides consultations on antimicrobial } \\
\text { susceptibility profiles associated with dif- } \\
\text { ferent sources to aid outbreak investiga- } \\
\text { tions } \\
\text { - Uploads PFGE patterns to PulseNet for } \\
\text { most NARMS Salmonella isolates from } \\
\text { retail meats and food animals } \\
\text { - Shares retail meat package information } \\
\text { with outbreak investigators }\end{array}$ & $\begin{array}{l}\text { - Enables public health agencies to prioritize inves- } \\
\text { tigation of outbreaks caused by drug-resistant } \\
\text { pathogens } \\
\text { - Helped identify ground turkey and chicken as } \\
\text { vehicles of two multistate Salmonella Heidelberg } \\
\text { outbreaks, resulting in industry changes and recall } \\
\text { of more than } 36 \text { million pounds of product } \\
\text { - Informs analyses that attribute resistant and sus- } \\
\text { ceptible infections to specific sources (foods, ani- } \\
\text { mals, etc.) }\end{array}$ \\
\hline $\begin{array}{l}\text { Epidemiologic and } \\
\text { microbiologic } \\
\text { research }\end{array}$ & $\begin{array}{l}\text { - Identifies risk factors for and clinical } \\
\text { impact of resistant enteric infections } \\
\text { through collaborations with FoodNet } \\
\text { - Helps attribute enteric infections to spe- } \\
\text { cific sources } \\
\text { - Performs molecular and genetic testing to } \\
\text { better understand mechanisms and sources } \\
\text { of resistant enteric infections } \\
\text { - Develops and validates methods to mea- } \\
\text { sure resistance and characterize enteric } \\
\text { bacteria } \\
\text { - Maintains a repository of resistant enteric } \\
\text { bacteria (isolate bank) for use by govern- } \\
\text { ment, academic, and industry researchers }\end{array}$ & $\begin{array}{l}\text { - Showed quinolone resistance is associated with } \\
\text { foreign travel (Salmonella Enteritidis and Campy- } \\
\text { lobacter) and poultry consumption outside the } \\
\text { home (Campylobacter) } \\
\text { - Found resistance is associated with bloodstream } \\
\text { infections and hospitalizations (Salmonella) and } \\
\text { prolonged diarrhea (Campylobacter) } \\
\text { - Developed the first standardized in vitro antimi- } \\
\text { crobial susceptibility testing method for Campylo- } \\
\text { bacter } \\
\text { - Identifies genes and mobile genetic elements } \\
\text { responsible for resistance } \\
\text { - Facilitates drug and diagnostic test development } \\
\text { through maintenance of an isolate bank }\end{array}$ \\
\hline $\begin{array}{l}\text { Communication } \\
\text { and outreach }\end{array}$ & $\begin{array}{l}\text { - Publishes online surveillance reports, in- } \\
\text { teractive graphs, and downloadable, } \\
\text { isolate-level data } \\
\text { - Reports results of human isolates testing to } \\
\text { submitting health agencies } \\
\text { - Collaborates with foreign scientists on } \\
\text { investigations and studies } \\
\text { - Provides consultations and trainings for } \\
\text { international surveillance and outbreak } \\
\text { investigation activities } \\
\text { - Serves on international advisory groups } \\
\text { and task forces } \\
\text { - Shares data with standard-setting organi- } \\
\text { zations to establish or revise interpretive } \\
\text { criteria }\end{array}$ & $\begin{array}{l}\text { - Provides data that inform antimicrobial stewardship } \\
\text { efforts, clinical practice, and industry policy and } \\
\text { practices } \\
\text { - Consults on establishment of surveillance programs } \\
\text { in other countries } \\
\text { - Provided data that supported lowering CLSI } \\
\text { fluoroquinolone breakpoints for Salmonella and } \\
\text { establishing azithromycin epidemiological cutoff } \\
\text { values for Shigella }\end{array}$ \\
\hline
\end{tabular}

CLSI, Clinical and Laboratory Standards Institute; FoodNet, Foodborne Diseases Active Surveillance Network; NARMS, National Antimicrobial Resistance Monitoring System; PFGE, pulsed-field gel electrophoresis. 
Table 2. Summary of Surveillance Conducted by the National Antimicrobial Resistance Monitoring System, 2016

\begin{tabular}{|c|c|c|c|}
\hline & Humans & Retail meats & Food animals \\
\hline $\begin{array}{l}\text { Federal agency leading } \\
\text { surveillance }\end{array}$ & $\mathrm{CDC}$ & FDA & USDA \\
\hline Geographic coverage & Nationwide $^{\mathrm{a}}$ & 14 States $^{b}$ & Nationwide \\
\hline Sample source(s) & Ill humans & $\begin{array}{l}\text { Chicken parts, ground turkey, } \\
\text { ground beef, and pork } \\
\text { chops from grocery stores }\end{array}$ & $\begin{array}{l}\text { Chickens, turkeys, and cattle } \\
\text { (carcass, ground, cecal) and } \\
\text { swine (carcass, cecal) from } \\
\text { slaughter plants }\end{array}$ \\
\hline Year testing began & 1996 & 2002 & $1997^{\mathrm{c}}$ \\
\hline $\begin{array}{l}\text { Bacteria tested (year } \\
\text { testing began) }\end{array}$ & $\begin{array}{l}\text { Non-Typhi } \\
\quad \text { Salmonella }(1996) \\
\text { Campylobacter }(1997) \\
\text { Escherichia coli O157 (1996) } \\
\text { Salmonella Typhi (1999) } \\
\text { Shigella }(1999) \\
\text { Vibrio }(2009)\end{array}$ & $\begin{array}{l}\text { Nontyphoidal } \\
\quad \text { Salmonella }(2002) \\
\text { Campylobacter }(2002)^{\mathrm{d}} \\
\text { E. coli }(2002)^{\mathrm{f}} \\
\text { Enterococcus }(2002)^{\mathrm{f}}\end{array}$ & $\begin{array}{l}\text { Nontyphoidal } \\
\quad \text { Salmonella }(1997)^{\mathrm{c}} \\
\text { Campylobacter }(1998)^{\mathrm{c}, \mathrm{e}} \\
\text { E. coli }(2000)^{\mathrm{c}} \\
\text { Enterococcus }(2003)^{\mathrm{c}}\end{array}$ \\
\hline
\end{tabular}

${ }^{a}$ NARMS human surveillance has been nationwide since 2003 except for Campylobacter, which is limited to selected laboratories in the 10 sites (Connecticut, Georgia, Maryland, Minnesota, New Mexico, Oregon, and Tennessee and selected counties in California, Colorado, and New York) participating in FoodNet.

${ }^{\mathrm{b}}$ The 14 states participating in NARMS retail meat surveillance since 2013 are the 10 FoodNet sites (Connecticut, Georgia, Maryland, Minnesota, New Mexico, Oregon, and Tennessee and selected counties in California, Colorado, and New York) and Louisiana, Missouri, Pennsylvania, and Washington.

${ }^{\mathrm{c} C}$ Carcass (chickens, turkeys, cattle, swine) and ground product (chicken, turkey, beef) sampling began in 1997 for nontyphoidal Salmonella. Testing of animal samples for Campylobacter, E. coli, and Enterococcus was limited to chicken carcasses until cecal sampling was added in 2013.

${ }^{\mathrm{d}}$ Due to low isolation of Campylobacter from retail ground beef and pork chops, testing of retail meats for Campylobacter has been limited to chicken parts and ground turkey since 2008.

${ }^{\mathrm{e}}$ Isolation of Campylobacter from chickens at slaughter began in 1998, but nalidixic acid susceptibility and cephalothin resistance were used by USDA as identification criteria for Campylobacter jejuni/coli until mid-2001, which likely resulted in underreporting of quinoloneresistant Campylobacter during this time.

${ }^{\mathrm{f}}$ Testing of retail meats for E. coli and Enterococcus is conducted at selected sites (Georgia, Oregon, Maryland, and Tennessee).

CDC, Centers for Disease Control and Prevention; FDA, U.S. Food and Drug Administration; FoodNet, Foodborne Diseases Active Surveillance Network; NARMS, National Antimicrobial Resistance Monitoring System; USDA, United States Department of Agriculture.

methods are available in NARMS surveillance reports (CDC, 2016; FDA, 2016a).

NARMS human surveillance began at CDC in 1996 with 14 public health departments and was nationwide by 2003. NARMS now tests a nationwide sample of clinical isolates of Salmonella, E. coli O157, Shigella, and Vibrio, as well as a sample of Campylobacter isolates from states participating in Foodborne Diseases Active Surveillance Network (FoodNet). (FoodNet is a collaborative program among CDC, 10 state health departments, USDA's Food Safety and Inspection Service [FSIS], and FDA that conducts active, populationbased surveillance for laboratory-confirmed infections transmitted commonly through food) (Henao, 2015).

NARMS food animal surveillance began at USDA in 1997 with testing of carcass and ground product samples collected for regulatory purposes at slaughter and processing plants. Because shifts in FSIS priorities and industry performance often result in sampling changes, and samples are affected by interventions in the plants, trend analyses and interspecies comparisons are challenging. To overcome these limitations, sampling of cecal contents from slaughtered chickens, turkeys, cattle (dairy and beef), and swine (market hogs and sows) was added to NARMS in 2013. Cecal samples, which more directly reflect the intestinal microflora of animals just before processing, are cultured for Salmonella, Campylobacter, E. coli, and Enterococcus.
NARMS retail meat surveillance began at FDA in 2002. Since 2013, all 10 FoodNet sites and 4 other state public health departments have participated. Retail chicken parts, ground turkey, ground beef, and pork chops are cultured for Salmonella, E. coli (selected sites), and Enterococcus (selected sites); chicken parts and ground turkey are also cultured for Campylobacter. During 2015 and 2016, sites doubled the number of samples collected each month. Five new sites will begin retail meat testing in 2017 .

\section{Detecting emerging resistance and assessing trends}

Using an integrated surveillance approach, NARMS has been able to detect emerging resistance threats and assess trends in resistance in the food chain. For example, NARMS found increasing resistance to ceftriaxone, a cephalosporin used to treat invasive salmonellosis, among nontyphoidal Salmonella from humans, food animals at slaughter, and retail meats, with resistance varying by serotype and source (FDA, 2012b, 2013a, 2015a; Medalla et al., 2013; CDC, 2016). A NARMS analysis found that ceftriaxone resistance among Salmonella serotypes Newport, Typhimurium, and Heidelberg isolates from humans strongly correlates with ceftriaxone resistance in isolates from ground beef, cattle, and poultry (chickens and turkeys), respectively, findings that support other evidence that specific food animals are 
important reservoirs of ceftriaxone-resistant Salmonella (Iwamoto et al., 2017).

Other types of emerging resistance detected by NARMS and linked to food animal sources include ciprofloxacin and gentamicin resistance in Campylobacter (Gupta et al., 2004; Kassenborg et al., 2004; Zhao et al., 2015a) and specific multidrug resistance phenotypes in Salmonella serotypes Dublin, Newport, and I 4,[5],12:1:- (Gupta et al., 2003; Varma et al., 2006; FDA, 2013a, 2015a, 2016a; CDC, 2015a).

\section{Outbreak Isolate Testing and Investigation}

NARMS provides data that aid the investigation of outbreaks. PFGE patterns for Salmonella isolates from NARMS retail meat and animal testing are uploaded to PulseNet; when one of these patterns matches that of an outbreak strain, the meat product or meat derived from that food animal class can be investigated as a possible source of the outbreak.

CDC NARMS began antimicrobial susceptibility testing of human clinical isolates from enteric disease outbreaks in the early 2000s and has expanded this testing over the past 5 years. CDC prioritizes testing of outbreak isolates, reports results to investigators immediately, and includes test results in outbreak summaries posted online. This testing allows CDC and health departments to prioritize investigation of outbreaks involving resistant pathogens. Moreover, because resistance profiles vary by source, they can provide important clues about the source of ongoing outbreaks. CDC also links NARMS outbreak isolate results with data in the National Outbreak Reporting System (NORS) to glean information about food and animal sources of resistant and susceptible human infections.

The value of NARMS in outbreak investigation was highlighted during two multistate Salmonella Heidelberg outbreaks. In 2011, PFGE patterns of multidrug-resistant Salmonella Heidelberg from human cases matched those from two ground turkey samples purchased as part of routine NARMS surveillance during the time of the outbreak. These matches led public health officials to target ground turkey as a possible source. In this outbreak, a total of 136 illnesses were reported from 34 states and the outbreak resulted in a recall of over 36 million pounds of ground turkey products, one of the largest FSIS Class I recalls in history (CDC, 2011; Routh et al., 2015). Because NARMS retail meat sites collect information from retail meat packages, NARMS data have also been used to link outbreak strains with the particular brands(s) involved. In 2012, when another multistate outbreak of Salmonella Heidelberg infections was investigated, NARMS retail chicken surveillance isolates matched the outbreak strain isolated from humans and were found to be significantly associated with a single poultry producer (Grinnell et al., 2013).

\section{NARMS Research-Characterizing Resistant Infections and Bacteria}

NARMS epidemiologists and microbiologists conduct research to characterize resistant infections and bacteria and better understand the spread of resistance. NARMS laboratories and databases house specimens and data for more than 200,000 bacterial strains from humans, food animals, and retail meats, making the program a natural platform for applied research.

\section{Epidemiologic research}

Epidemiologic studies using NARMS data have advanced our understanding of resistance trends, risk factors for acquiring resistant enteric infections, and clinical outcomes of resistant infections. Many studies have linked data from NARMS with data from FoodNet or other surveillance systems, enhancing the value of each system. The studies have informed policy changes, regulatory actions, and recommendations aimed at reducing resistant infections.

Collaborations among scientists from NARMS and other public health surveillance systems have helped to identify risk factors for human infections with antimicrobial-resistant pathogens. A FoodNet-NARMS case-control study identified international travel and eating poultry at a commercial establishment as risk factors for acquiring fluoroquinolone-resistant Campylobacter infections (Kassenborg et al., 2004). Another case-control study and a field investigation found that consuming uncooked ground beef, consuming runny scrambled eggs or omelets prepared in the home, taking an antimicrobial agent to which the strain is resistant, and exposure to a dairy farm were risk factors for infection with multidrug-resistant Salmonella Newport, which emerged and became widely disseminated in humans and cattle in the United States in the late 1990s and early 2000s (Gupta et al., 2003; FDA, 2006; Varma et al., 2006). Antimicrobial use in humans was found to be a risk factor for infection with multidrug-resistant Salmonella Typhimurium in another study (Glynn et al., 2004).

Greene et al. (2008) found no significant differences in region of residence or age distribution when patients with multidrug-resistant and pansusceptible Typhimurium infections were compared. However, the authors found that multidrug-resistant Newport infections were less commonly found in the South census region and in children $<2$ years of age compared with pansusceptible Newport infections. Using linked data from NARMS and FoodNet, O'Donnell et al. (2014) found that the majority of patients with nalidixic acidresistant Salmonella Enteritidis infections had recently travelled to another country, critical information for evaluating the consequences of domestic quinolone use and for identifying possible sources of domestically acquired quinoloneresistant infections, such as imported seafood and spices (Bae et al., 2016). Phenotypic susceptibility data from NARMS and PFGE data from PulseNet and NARMS have been used in microbial subtyping models for Salmonella Hadar to attribute most human infections to turkey (Vieira et al., 2016).

Studies linking NARMS data with FoodNet and outbreak data suggest that resistant infections have worse clinical outcomes than susceptible ones. Antimicrobial-resistant Salmonella infections were found to be associated with more bloodstream infections, hospitalizations, and hospitalizations that were longer than $3 \mathrm{~d}$ compared with pansusceptible infections (Varma et al., 2005a, 2005b; Krueger et al., 2014). Nelson et al. (2004) found that ciprofloxacin-resistant Campylobacter infections result in a longer duration of diarrhea than ciprofloxacin-susceptible infections.

\section{Microbiologic research}

NARMS has played a central role in developing and expanding methods to measure and understand the context of antimicrobial resistance. NARMS contributions to phenotypic susceptibility testing methods include development of 
the first standardized in vitro antimicrobial susceptibility testing methods for Campylobacter (McDermott et al., 2004, 2005), publication of a pefloxacin disk diffusion method for Salmonella fluoroquinolone resistance screening (Skov et al., 2015), and definition of the susceptible azithromycin minimum inhibitory concentration (MIC) range for Shigella (Howie et al., 2010). NARMS microbiologists have also developed polymerase chain reaction- and microarray-based methods for molecular detection of resistance (Gay et al., 2006; Jackson et al., 2007; Frye et al., 2010) and demonstrated that whole genome sequencing (WGS) can predict antimicrobial resistance with a high degree of accuracy in nontyphoidal Salmonella (McDermott et al., 2016), Campylobacter (Zhao et al., 2015b), and E. coli (Tyson et al., 2015).

NARMS scientists and collaborators have used NARMS isolates for bacterial genetic studies that have improved our understanding of the nature, behavior, and sources of antimicrobial resistance and the genes, mobile DNA elements, and mutations responsible for resistance. These studies have helped to characterize emerging cephalosporin, aminoglycoside, and quinolone resistance genes in Salmonella (Zhao et al., 2001; Folster et al., 2009; Sjölund-Karlsson et al., 2009), aminoglycoside resistance genes in Campylobacter (Zhao et al., 2015a), and macrolide resistance genes in Shigella (Howie et al., 2010). Early studies identified the genes responsible for high-level gentamicin and streptogramin resistance in Enterococcus (Jackson et al., 2005, 2007, 2008). NARMS scientists have also identified the contribution of efflux pumps and mutations in topoisomerase and 23s ribosomal RNA (rRNA) genes to resistance or decreased susceptibility to fluoroquinolones and macrolides (Ge et al., 2005; Whichard et al., 2007; Ladely et al., 2009).

Comparing strains of enteric bacteria from the different sampling sources is a key component of NARMS integrated surveillance. NARMS studies have shown that certain bacterial subtypes, antimicrobial resistance, and mobile elements (e.g., plasmids and integrons) tend to come from particular food animal sources, some of which are also associated with human disease. For example, NARMS researchers found that the increase in cephalosporin resistance in Salmonella Heidelberg in 2009 was due to the dissemination of plasmid-encoded $b l a_{\mathrm{CMY}}$ genes, and the identification of identical sequence types for IncI1 plasmids in strains from humans, chicken carcasses, and retail chicken breasts supported other evidence that chicken products are an important source of human infection (Folster et al., 2012). A study of cephalosporin-resistant Salmonella Typhimurium found that while most isolates had plasmidencoded $b l a_{\mathrm{CMY}}$ genes, nearly all isolates from chicken sources had IncI1-bla $a_{\mathrm{CMY}}$ plasmids, while those from cattle had IncA/ C-bla $a_{\text {CMY }}$ plasmids (Folster et al., 2014), information that can help identify sources of human Typhimurium infections and refine targeted interventions aimed at limiting resistance at its source.

Molecular studies of NARMS isolates from different sources can also provide information about how resistance spreads. For example, when NARMS detected emerging multidrug resistance in Salmonella Albert isolates from humans, retail ground turkey, and turkeys at slaughter, molecular characterization of isolates and their plasmids suggested that resistance was the result of horizontal gene transfer rather than clonal expansion (Folster et al., 2015).

\section{On-farm pilot studies}

In 2011, USDA's Agricultural Research Service developed pilot studies (e.g., Schmidt et al., 2015; Webb et al., 2016) with federal, academic, and industry scientists to explore the prospects for a preharvest surveillance component in NARMS. The studies determined the logistical and technical challenges associated with gathering data and isolates from major food animal species and production types. The studies investigated the prevalence of resistance in select dairy cattle, beef cattle, swine, broiler, and turkey farms, providing data on the relationship between on-farm and slaughter plant resistance profiles. They also explored the feasibility of obtaining species-specific antimicrobial use data on farms, data that are urgently needed to understand the drivers of resistance in agricultural settings and assess the impact of antimicrobial stewardship initiatives and other interventions (CDC, 2013; WHO, 2013, 2014; White House, 2015). Knowledge gained and lessons learned from these pilot studies are assisting in the development of new food animal surveillance programs focused on the collection of data on antimicrobial use and resistance in animal agriculture.

\section{Data for Regulatory Actions and Policy}

Data from NARMS are used for regulatory and policy decision-making related to antimicrobial drug approvals, as well as the implementation and assessment of public health interventions. Figure 1 shows a timeline with selected NARMS activities and related policy and regulatory actions.

NARMS data are used in preapproval risk assessments for food animal antimicrobial drugs, where human food safety implications must be considered (Gilbert et al., 2007). FDA recommends a qualitative risk assessment approach outlined in FDA guidance No. 152 (FDA, 2003). In this type of safety review, resistance trends and types, along with information on genetic mechanisms of resistance and pathogen prevalence, are evaluated taking into consideration the importance of the antimicrobial class for use in human medicine; the process for ranking antimicrobial classes is described in Appendix A of the guidance (FDA, 2003). NARMS data are also used to devise risk management strategies that limit resistance associated with the use of FDA-approved antimicrobial products in food animals (FDA, 2003).

Antimicrobial resistance data are also vital to FDA's postapproval safety monitoring efforts and policies. For example, NARMS data informed FDA policy on the use, in food animals, of fluoroquinolones and cephalosporins, two critically important antimicrobial classes for human health (FDA, 2003; Collignon et al., 2016). Data from NARMS and other sources showed a rise in fluoroquinolone resistance among Campylobacter from humans following the approvals of sarafloxacin (1995) and enrofloxacin (1996) in poultry, that poultry was a source of human infection, and that fluoroquinolone-resistant Campylobacter infections in humans were a health hazard (Smith et al., 1999; FDA, 2000, 2005a; Gupta et al., 2004; Kassenborg et al., 2004; Nelson et al., 2004). FDA used these data to conduct a quantitative risk assessment (FDA, 2001a) and to support the withdrawal of the poultry approvals for sarafloxacin in 2001 and, after a lengthy hearing, enrofloxacin in 2005 (FDA, 2001b, 2005a, 2005b; Nelson et al., 2007). Withdrawal of the poultry fluoroquinolone approvals marked the first time animal drugs 


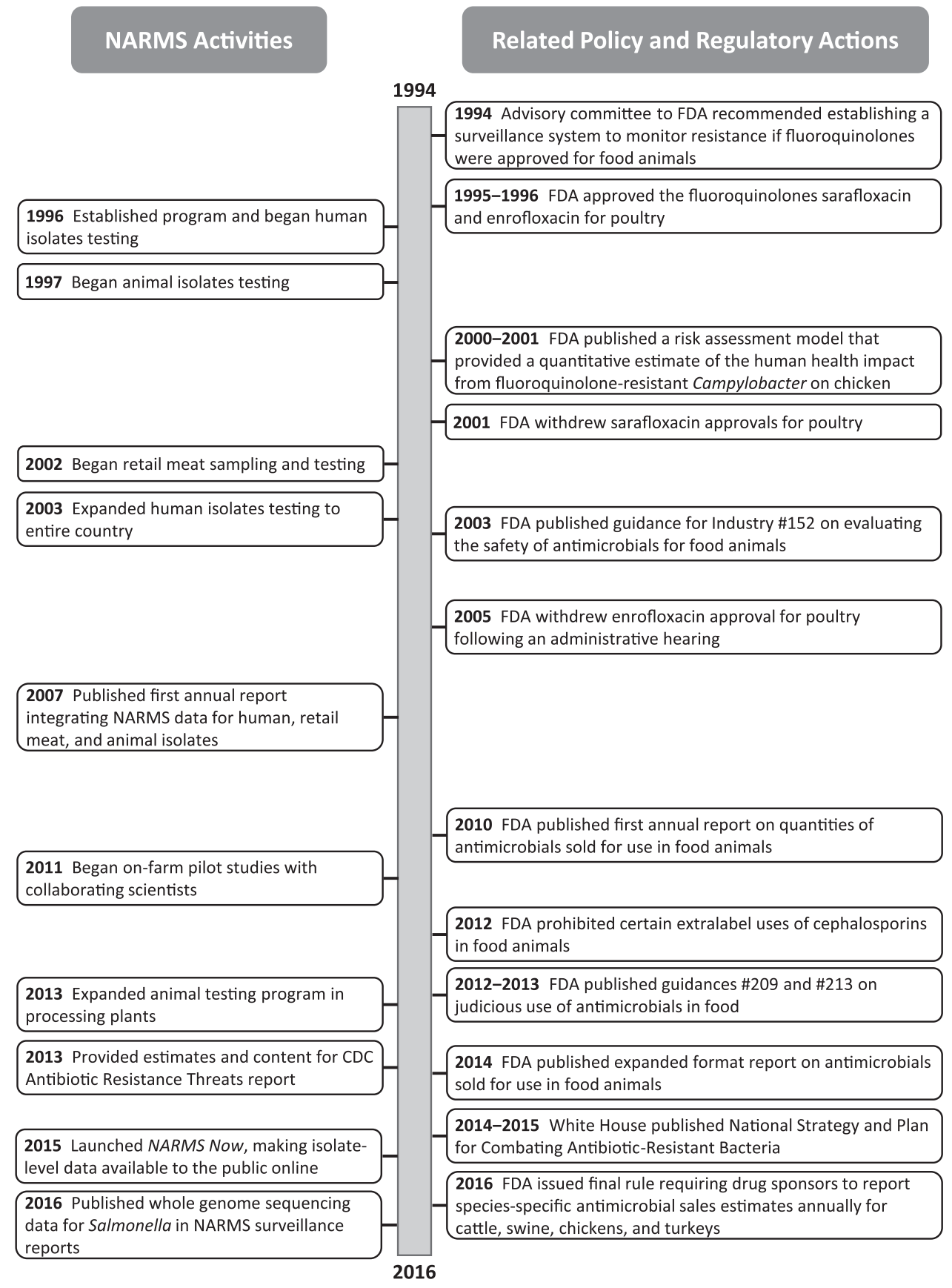

FIG 1. Selected NARMS activities and related policy and regulatory actions, 1994-2016. NARMS, National Antimicrobial Resistance Monitoring System.

were removed from the market because of the associated emergence of resistance in humans (Nelson et al., 2007). Data from NARMS and other sources showed a rise in resistance to third-generation cephalosporins among Salmonella isolates from food animals at slaughter, retail meats, and humans, which prompted FDA to issue an order prohibiting certain extralabel uses of cephalosporins in cattle, swine, chickens, and turkeys in 2012 (FDA, 2012b).

Data from NARMS and other sources will be used to help assess the impact of FDA guidance No. 213 (FDA, 2013b). This guidance, which took effect on January 1, 2017, will result in the phasing out of the use of medically important antimicrobial drugs in feed or water for animal production (e.g., growth promotion) purposes and phasing in veterinary oversight for therapeutic uses of these drugs in food animals; veterinary feed directives and prescriptions will be required to administer medically important antimicrobial drugs in feed and water, respectively (FDA, 2013c, 2014).

CDC has also used NARMS data for policy-related activities. The U.S. Department of Health and Human Service's Healthy People initiative provides science-based 10-year national objectives for improving the health of Americans. NARMS data are used for assessing progress on several food safety objectives in Healthy People 2020 related to antimicrobial resistance in Salmonella and Campylobacter isolates from humans (DHHS, 2016). 
NARMS data have also been used to estimate the number of illnesses and deaths in the United States caused by drugresistant Campylobacter, nontyphoidal Salmonella, Salmonella Typhi, and Shigella. These estimates were published in a landmark CDC report entitled Antibiotic Resistance Threats in the United States, 2013 (CDC, 2013). Publication of the report was followed by several White House-level actions related to combating antimicrobial resistance, including release of a presidential executive order and publication of a national strategy and action plan for combating antibiotic-resistant bacteria (White House, 2014a, 2014b, 2015).

\section{Communication and Outreach}

\section{Reporting NARMS surveillance data}

Data reporting is a challenge for integrated antimicrobial resistance surveillance systems due to the quantity and complex nature of the data and the need to communicate it to a diverse range of stakeholders. NARMS scientists produce annual NARMS Integrated Reports that aggregate data on bacteria recovered from humans, retail meats, and food animals at slaughter (FDA, 2015a, 2016a). These reports summarize trends in the prevalence of resistance to antimicrobial drugs important in human and veterinary medicine and specific multidrug-resistance patterns, including those linked to severe illness in humans. An emphasis is placed on reporting resistance that is important for human health. NARMS agencies use comparable laboratory methods and meet regularly to reach consensus on data reporting. To facilitate integrated reporting, FDA maintains a database that houses NARMS data for human, retail meat, and animal isolates. CDC also produces annual NARMS reports with more detailed resistance data for zoonotic and nonzoonotic enteric bacterial pathogens isolated from humans (CDC, 2016).

NARMS data are readily available to the public online. NARMS has developed a number of tools to make surveillance findings transparent and accessible to both scientists and nonspecialists. Since 2009, the integrated report has been accompanied by online interactive graphs that allow users to visualize findings across sample sources, drugs, and years. To provide timely downloadable data in a user-friendly format, NARMS Now was launched in 2015. NARMS Now: Integrated Data has data for NARMS nontyphoidal Salmonella and Campylobacter surveillance isolates from all sources and for NARMS Enterococcus and E. coli isolates from food animals at slaughter and retail meats (FDA, 2015b). NARMS Now: Human Data has downloadable data for Salmonella (typhoidal and nontyphoidal), Campylobacter, Shigella, and E. coli $\mathrm{O} 157$ surveillance isolates from humans (CDC, 2015b). Both NARMS Now sites include interactive graphs, tables, maps, and downloadable data. NARMS Now will include links to the genomic sequence data submitted to the National Center for Biotechnology Information (NCBI) at the National Institutes of Health as they become available.

\section{Working with standard-setting organizations}

NARMS scientists work with consensus organizations like the Clinical and Laboratory Standards Institute (CLSI) and the European Committee on Antimicrobial Susceptibility Testing (EUCAST) to provide data that inform antimicrobial susceptibility testing methods and development of interpre- tive criteria, including clinical breakpoints and epidemiological cutoff values (ECVs or ECOFFs); the latter are based on MIC distributions. Broth microdilution methods and quality control ranges for Campylobacter susceptibility testing established by FDA NARMS scientists were approved and published by CLSI (McDermott et al., 2004, 2005; CLSI, 2006). Clinical outcomes data along with NARMS human clinical isolates data were used to revise fluoroquinolone clinical breakpoints for Salmonella (CLSI, 2012), and collaborative studies have resulted in updates to fluoroquinolone disk diffusion interpretive criteria for Salmonella (CLSI, 2015), as well as azithromycin broth microdilution and disk diffusion ECVs for Shigella (CLSI, 2016). Through such collaborations and data sharing, NARMS augments the scientific basis for setting interpretive criteria for susceptibility testing, serving both surveillance and clinical medicine purposes.

\section{Participating in international activities}

Antimicrobial resistance is a global problem and cited by WHO as one of the top health challenges (WHO, 2015). With extensive and expanding global trade and travel, international activities and collaborations are very important for monitoring and combating resistance. As members of the WHO Advisory Group on Integrated Surveillance of Antimicrobial Resistance (AGISAR), NARMS scientists have provided advice and helped develop a document to guide countries in designing surveillance programs to monitor resistance in the food chain (WHO, 2013). The federal agencies participating in NARMS have also provided trainings on foodborne disease and antimicrobial resistance surveillance and have supported investigations and capacity-building activities in developing countries. In addition, NARMS has collaborated with well-established antimicrobial resistance monitoring programs in several countries and has ongoing collaborations with the Canadian Integrated Program for Antimicrobial Resistance Surveillance (CIPARS). NARMS scientists have served on international resistance task forces, including the ad hoc Codex Intergovernmental Task Force on Antimicrobial Resistance, which developed Guidelines for Risk Analysis of Foodborne Antimicrobial Resistance (Codex Alimentarius Commission, 2011), and the Transatlantic Task Force on Antimicrobial Resistance (TATFAR), which works to enhance collaborations between the United States and the European Union.

\section{The Future}

\section{New technologies: challenges and opportunities}

New technologies, such as WGS and culture-independent diagnostic testing (CIDT), present opportunities and challenges for NARMS surveillance. WGS is poised to transform the microbiology laboratory by providing an unprecedented level of detail about bacteria and reducing a series of specialized tests to a single comprehensive analytical workflow. WGS allows rapid screening of bacteria for the genetic determinants of genus, species, serotype, subtype, pathotype, and antimicrobial resistance. This makes it possible to quickly distinguish genetic determinants of resistance, greatly enhancing our ability to compare and contrast strains of bacteria from different sources. WGS can not only assist in 
tracking resistance trends and mechanisms but also help solve outbreaks, including those caused by resistant pathogens, by providing high discriminatory power (Deng et al., 2016). In addition, WGS can be used retrospectively to look for newly identified resistance genes, even for resistance to drugs that are not under surveillance, all without entering the laboratory.

Implementing WGS nationwide for food safety purposes poses both technological and operational challenges that will require changes in infrastructure and expertise. Technologies are rapidly evolving and standardized methods with quality controls must be used by staff in dozens of public health laboratories trained to use newly-acquired sequencers. Data systems will need to be adapted to house, manage, and transmit the volume of data generated by WGS. Allele databases for major foodborne pathogens are still being developed and there is an urgent need for bioinformatics tools and expertise (Deng, 2016). Since WGS cannot identify novel resistance genes, phenotypic susceptibility testing of some isolates will still be necessary to detect emerging resistance, and ongoing curation of resistance gene databases will be needed to add new genes as they are found.

CIDT, which is increasingly being adopted by clinical laboratories, presents challenges to surveillance systems based on traditional microbiology. While CIDT offers many benefits, such as rapid turnaround time, it reduces the number of isolates available for antimicrobial susceptibility testing. Until methods are developed that identify pathogens and their properties directly from specimens, "reflex culturing", (culturing a sample with a positive CIDT) is needed (Henao et al., 2015; Iwamoto et al., 2015; Huang et al., 2016). New strategies, for example, metagenomics, single cell sequencing, or targeting specific amplicons, could make it possible to catalog the "resistome" in a biological sample, identifying all resistance genes present regardless of the bacterial source.

\section{NARMS as a platform for addressing emerging issues}

NARMS' infrastructure and partnerships provide it with the flexibility needed to answer important public health questions about emerging resistance and pathogens. NARMS can use existing sample sources for ad hoc studies, such as those that assessed the prevalence of methicillin-resistant Staphylococcus aureus (Ge et al., 2017), vancomycinresistant enterococci, and Clostridium difficile in retail meats. When the colistin resistance gene $m c r-1$ was discovered on a transferable plasmid in $E$. coli isolates from animals and raw meat and E. coli and Klebsiella pneumoniae isolates from humans in China in 2015 (Liu et al., 2016), NARMS scientists used WGS data to confirm that this mechanism was not present in over 55,000 enteric bacteria (Salmonella, E. coli, Shigella) that had been sequenced, including over 5000 Salmonella from NARMS. Furthermore, USDA scientists incubated 2000 NARMS cecal content samples in culture medium enriched with colistin and found that the gene $\mathrm{mcr}-1$ was present in two $E$. coli strains isolated from swine (Meinersmann et al., 2016a, 2016b, 2017).

Sampling can also be expanded within NARMS to food animals or retail food products not currently tested, such as seafood, which is largely imported from countries with extensive antimicrobial use in aquaculture (Sapkota et al., 2008; NMFS, 2015; FDA, 2016b). NARMS has also begun to explore using imported food testing data from FDA's Office of Regulatory Affairs to identify possible food vehicles for resistant infections that have not been linked to domestic food sources or international travel.

Long-standing partnerships with other surveillance programs, such as FoodNet, can continue to facilitate epidemiologic investigations of emerging resistance. Partnerships between NARMS and Vet-LIRN, the Veterinary Laboratory Investigation and Response Network (FDA, 2016d), will continue to expand and can help address the potential role of companion animals in the ecology of resistance, while broadening interdisciplinary collaborations could help provide a better understanding of the role of environmental pathways (e.g., water, soil, wastes, wildlife) in the dissemination of resistant organisms, both of which are underexplored areas in the One Health model (Lloyd, 2007; Finley et al., 2013). Other programs conduct surveillance for animal pathogens, including those that are zoonotic, and there may be opportunities for NARMS to collaborate on specific projects, especially as the use of WGS expands.

Through the Antibiotic Resistance Solutions Initiative (CDC, 2017), CDC is supporting state and local health departments to expand WGS capacity to include screening all Salmonella and many more Campylobacter and Shigella isolates from humans for resistance genes and to collect more epidemiologic data from patients with resistant infections. These activities should enhance detection of emerging resistance and assessment of resistance trends, aid identification of sources and outcomes of resistant infections, and help prioritize investigation of resistant outbreaks. FDA's planned expansion of retail meat surveillance to more sites will increase the geographic representativeness of sampling and the sample size, providing more information about emerging resistance in food animal sources.

\section{Antimicrobial sales and use data}

A long-standing gap in NARMS has been the lack of detailed antimicrobial use data in food-producing animals in the United States. Currently, only a limited amount of data is available on the quantities of antimicrobial drugs sold and distributed for use in food animals in the United States. Without knowing how a specific antimicrobial drug is used in each type of food animal, it is difficult to fully evaluate the drivers of resistance or to assess the impact of interventions (WHO, 2013; FAO, 2016). Therefore, FDA has recently expanded antimicrobial sales data reporting requirements for drug sponsors to include species-specific estimates for cattle, swine, chickens, and turkeys (FDA, 2016c) and, through cooperative agreements, plans to fund projects to enhance monitoring of antimicrobial use in food animals. In addition, USDA's National Animal Health Monitoring System (NAHMS) has designed surveys for antimicrobial use data collection on farms in 2017. The data collected from these initiatives will help to guide antimicrobial stewardship efforts and support microbial food safety risk assessments.

\section{Conclusion}

NARMS is a long-standing, multiagency collaborative program that provides essential information about antimicrobial resistance in enteric bacteria and serves as an efficient and flexible platform for detecting and characterizing 
emerging resistance threats in humans, food animals, and food. NARMS data have been widely used to formulate science-based policies, regulatory actions, educational efforts, and other initiatives aimed at reducing resistance and preventing human infections. Many improvements have been made to NARMS over the past two decades, and the program will continue to change as bacteria evolve and new technologies become available.

Continued use of an integrated One Health approach to surveillance and research is critical for effectively addressing the complex and multifaceted problem of antimicrobial resistance. Such an approach facilitates detection of emerging resistance threats and trends, data comparisons, and generation of hypotheses about sources of resistant and susceptible infections. Securing more detailed data about on-farm management practices, including the quantities of antimicrobials used in each food animal species, and analyzing these data in conjunction with resistance data will help us better understand resistance trends and facilitate identification and evaluation of targeted interventions designed to reduce resistance and protect public health.

\section{Acknowledgments}

The authors thank state and local health departments for their participation in NARMS, as well as the many epidemiologists and microbiologists at FDA, CDC, and USDA who have contributed to the program, particularly Linda Tollefson, Fred Angulo, Paula Fedorka-Cray, and Tim Barrett for their vision and leadership in founding the program two decades ago, and David White who led NARMS activities at FDA, the lead agency for NARMS.

\section{Disclosure Statement}

No competing financial interests exist.

\section{References}

Bae D, Kweon O, Khan AA. Isolation and characterization of antimicrobial-resistant nontyphoidal Salmonella enterica serovars from imported food products. J Food Prot 2016; 79:1348-1354.

[CDC] Centers for Disease Control and Prevention. Multistate Outbreak of Human Salmonella Heidelberg Infections Linked to Ground Turkey (Final Update). 2011. Available at: www .cdc.gov/salmonella/2011/ground-turkey-11-10-2011.html, accessed September 2, 2016.

CDC. Antibiotic Resistance Threats in the United States, 2013. Atlanta, GA: U.S. Department of Health and Human Services, 2013. Available at: www.cdc.gov/drugresistance/threatreport-2013/, accessed September 2, 2016.

CDC. National Antimicrobial Resistance Monitoring System for Enteric Bacteria (NARMS): Human Isolates Final Report, 2013. Atlanta, GA: U.S. Department of Health and Human Services, CDC, 2015a. Available at: www.cdc.gov/narms/ reports/index.html, accessed September 2, 2016.

CDC. NARMS Now: Human Data. 2015b. Available at: wwwn .cdc.gov/narmsnow/, accessed September 2, 2016.

CDC. National Antimicrobial Resistance Monitoring System for Enteric Bacteria (NARMS): Human Isolates Surveillance Report for 2014 (Final Report). Atlanta, GA: U.S. Department of Health and Human Services, CDC, 2016. Available at: www.cdc.gov/narms/reports/index.html, accessed September 2, 2016.

CDC. Antibiotic Resistance Solutions Initiative. 2017. Available at: www.cdc.gov/drugresistance/solutions-initiative/, accessed April 6, 2017.

[CLSI] Clinical and Laboratory Standards Institute. Methods for Antimicrobial Dilution and Disk Susceptibility Testing of Infrequently Isolated or Fastidious Bacteria; Approved Guideline. CLSI Document M45-A. Wayne, PA: CLSI, 2006.

CLSI. Performance Standards for Antimicrobial Susceptibility Testing. 22nd Informational Supplement. CLSI Supplement M100-S22. Wayne, PA: CLSI, 2012.

CLSI. Performance Standards for Antimicrobial Susceptibility Testing. 25th Informational Supplement. CLSI Supplement M100-S25. Wayne, PA: CLSI, 2015.

CLSI. Performance Standards for Antimicrobial Susceptibility Testing. 26th ed. CLSI Supplement M100S. Wayne, PA: CLSI, 2016.

Codex Alimentarius Commission. Guidelines for Risk Analysis of Foodborne Antimicrobial Resistance. 2011. Available at: www.codexalimentarius.net/download/standards/11776/CXG_ 077e.pdf, accessed September 2, 2016.

Collignon PC, Conly JM, Andremont A, McEwen SA, AidaraKane A; World Health Organization Advisory Group, Bogotá Meeting on Integrated Surveillance of Antimicrobial Resistance (WHO-AGISAR). World Health Organization Ranking of Antimicrobials According to Their Importance in Human Medicine: A Critical Step for Developing Risk Management Strategies to Control Antimicrobial Resistance from Food Animal Production. Clin Infect Dis 2016;63:1087-1093.

Deng X, den Bakker HC, Hendriksen RS. Genomic epidemiology: Whole-genome-sequencing-powered surveillance and outbreak investigation of foodborne bacterial pathogens. Annu Rev Food Sci Technol 2016;7:353-374.

[DHHS] U.S. Department of Health and Human Services. Healthy People 2020 Food Safety Objectives. 2016. Available at: www.healthypeople.gov/2020/topics-objectives/topic/foodsafety/objectives, accessed September 2, 2016.

[FAO] Food and Agriculture Organization. The FAO Action Plan on Antimicrobial Resistance 2016-2020. 2016. Available at: www.fao.org/3/a-i5996e.pdf, accessed September 21, 2016.

[FDA] U.S. Food and Drug Administration. Summary Minutes, Joint Meeting of the Veterinary Medicine Advisory Committee and Division of Anti-Infective Drugs Advisory Committee, Fluoroquinolones in Food Animal Medicine. May 11-12, 1994. 1994a. FDA Docket No. 00N-1571, Volume 61, DDI1, G-220.

FDA. Transcript of the Joint Meeting of the Veterinary Medicine Advisory Committee and Anti-Infective Drugs Advisory Committee, May 11-12, 1994. 1994b. FDA Docket No. 00N1571, Volume 61, DDI1, G-219.

FDA. Enrofloxacin for poultry; opportunity for hearing, notice. Fed Regist 2000;65:64954-64965.

FDA. Human Health Impact of Fluoroquinolone Resistant Campylobacter Attributed to the Consumption of Chicken. 2001a. Available at: www.fda.gov/ohrms/dockets/98fr/bkg0002. pdf, accessed September 2, 2016.

FDA. Animal drugs, feeds, and related products; sarafloxacin for poultry; withdrawal of approval of NADAs, final rule. Fed Regist 2001b;66:21282. Codified at 21 CFR $\S 520,522$, and 556.

FDA. Guidance for Industry \#152: Evaluating the Safety of Antimicrobial New Animal Drugs with Regard to their Microbiological Effects on Bacteria of Human Health Concern. 2003. Available at: www.fda.gov/downloads/AnimalVeterinary/ 
GuidanceComplianceEnforcement/GuidanceforIndustry/ UCM052519.pdf, accessed September 2, 2016.

FDA. Final Decision of the Commissioner. Docket No. 2000N1571. Withdrawal of Approval of the New Animal Drug Application for Enrofloxacin in Poultry. 2005a. Available at: www. fda.gov/AnimalVeterinary/SafetyHealth/RecallsWithdrawals/ ucm042004.htm, accessed September 2, 2016.

FDA. Animal drugs, feeds, and related products; enrofloxacin for poultry; withdrawal of approval of new animal drug application, final rule. Fed Regist 2005b;70:44048-44049. Codified at 21 CFR $\S 520$ and 556.

FDA. National Antimicrobial Resistance Monitoring SystemEnteric Bacteria: 2003 Executive Report. 2006. Available at: www.fda.gov/downloads/AnimalVeterinary/SafetyHealth/ AntimicrobialResistance/NationalAntimicrobialResistance MonitoringSystem/UCM061471.pdf, accessed September 2, 2016.

FDA. The National Antimicrobial Resistance Monitoring System (NARMS) Strategic Plan 2012-2016. 2012a. Available at: www.fda.gov/downloads/AnimalVeterinary/SafetyHealth/ AntimicrobialResistance/NationalAntimicrobialResistance MonitoringSystem/UCM236283.pdf, accessed September 2, 2016.

FDA. New animal drugs; cephalosporin drugs; extralabel animal drug use; order of prohibition. Fed Regist 2012b;77:735745. Codified at 21 CFR $\S 530$.

FDA. National Antimicrobial Resistance Monitoring SystemEnteric Bacteria (NARMS): 2011 Executive Report. 2013a. Available at: www.fda.gov/downloads/AnimalVeterinary/ SafetyHealth/AntimicrobialResistance/NationalAntimicrobial ResistanceMonitoringSystem/UCM407962.pdf, accessed November 21, 2016.

FDA. Guidance for Industry \#213: New Animal Drugs and New Animal Drug Combination Products, Administered in or on Medicated Fees or Drinking Water of Food-Producing Animals: Recommendations for Drug Sponsors for Voluntarily Aligning Product Use Conditions with GFI \#209. 2013b. Available at: www.fda.gov/downloads/Animal Veterinary/GuidanceComplianceEnforcement/Guidancefor Industry/UCM299624.pdf, accessed September 2, 2016.

FDA. Phasing Out Certain Antibiotic Use in Farm Animals. 2013c. Available at: www.fda.gov/forconsumers/consumerupdates/ ucm378100.htm, accessed September 2, 2016.

FDA. FDA Secures Full Industry Engagement on Antimicrobial Resistance Strategy. 2014. Available at: www.fda.gov/ animalveterinary/newsevents/cvmupdates/ucm403285.htm, accessed September 2, 2016.

FDA. NARMS Integrated Report: 2012-2013. 2015a. Available at: www.fda.gov/AnimalVeterinary/SafetyHealth/Antimicrobial Resistance/NationalAntimicrobialResistanceMonitoring System/ucm059103.htm, accessed September 2, 2016.

FDA. NARMS Now: Integrated Data. 2015b. Available at: www .fda.gov/AnimalVeterinary/SafetyHealth/AntimicrobialResistance/ NationalAntimicrobialResistanceMonitoringSystem/ucm416741 .htm, accessed January 17, 2017.

FDA. NARMS Integrated Report: 2014. 2016a. Available at: www.fda.gov/AnimalVeterinary/SafetyHealth/Antimicrobial Resistance/NationalAntimicrobialResistanceMonitoringSystem/ ucm059103.htm, accessed November 21, 2016.

FDA. Import Alert \# 16-131. Detention Without Physical Examination of Aquacultured, Shrimp, Dace, and Eel from China-Presence of New Animal Drugs and/or Unsafe Food Additives. 2016b. Available at: www.accessdata.fda.gov/cms_ ia/importalert_33.html, accessed September 22, 2016.
FDA. Antimicrobial Animal Drug Sales and Distribution Reporting. Fed Regist 2016c;81:29129-29141. Codified at 21 CFR $\S 514.80$ and $\S 514.87$.

FDA. Veterinary Laboratory Investigation and Response Network. 2016d. Available at: www.fda.gov/AnimalVeterinary/ ScienceResearch/ucm247334.htm, accessed January 17, 2017.

Finley RL, Collignon P, Larsson DG, McEwen SA, Li XZ, Gaze WH, Reid-Smith R, Timinouni M, Graham DW, Topp E. The scourge of antibiotic resistance: The important role of the environment. Clin Infect Dis 2013;57:704-710.

Folster JP, Campbell D, Grass J, Brown AC, Bicknese A, Tolar B, Joseph LA, Plumblee JR, Walker C, Fedorka-Cray PJ, Whichard JM. Identification and characterization of multidrug-resistant Salmonella enterica serotype Albert isolates in the United States. Antimicrob Agents Chemother 2015; 59:2774-2779.

Folster JP, Pecic G, Singh A, Duval B, Rickert R, Ayers S, Abbott J, McGlinchey B, Bauer-Turpin J, Haro J, Hise K, Zhao S, Fedorka-Cray PJ, Whichard J, McDermott PF. Characterization of extended-spectrum cephalosporinresistant Salmonella enterica serovar Heidelberg isolated from food animals, retail meat, and humans in the United States 2009. Foodborne Pathog Dis 2012;9:638-645.

Folster JP, Rickert R, Barzilay EJ, Whichard JM. Identification of the aminoglycoside resistance determinants $\operatorname{armA}$ and $r m t C$ among non-Typhi Salmonella isolates from humans in the United States. Antimicrob Agents Chemother 2009;53: 4563-4564.

Folster JP, Tolar B, Pecic G, Sheehan D, Rickert R, Hise K, Zhao S, Fedorka-Cray PJ, Whichard JM. Characterization of $b l a_{\mathrm{CMY}}$ plasmids and their possible role in source attribution of Salmonella enterica serotype Typhimurium infections. Foodborne Pathog Dis 2014;11:301-306.

Frye JG, Lindsey RL, Rondeau G, Porwollik S, Long F, McClelland M, Jackson CR, Englen MD, Meinersmann RJ, Berrang ME, Davis JA, Barrett JB, Turpin JB, Thitaram SN, Fedorka-Cray PJ. Development of a DNA microarray to detect antimicrobial resistance genes identified in the National Center for Biotechnology Information database. Microb Drug Resist 2010;16:9-19.

Gay K, Robicsek A, Strahilevitz J, Park CH, Jacoby G, Barrett TJ, Medalla F, Chiller TM, Hooper DC. Plasmid-mediated quinolone resistance in non-Typhi serotypes of Salmonella enterica. Clin Infect Dis 2006;43:297-304.

Ge B, McDermott PF, White DG, Meng J. Role of efflux pumps and topoisomerase mutations in fluoroquinolone resistance in Campylobacter jejuni and Campylobacter coli. Antimicrob Agents Chermother 2005;49:3347-3354.

Ge B, Mukherjee S, Hsu CH, Davis JA, Tran TT, Yang Q, Abbott JW, Ayers SL, Young SR, Crarey ET, Womack NA, Zhao S, McDermott PF. MRSA and multidrug-resistant Staphylococcus aureus in U.S. retail meats, 2010-2011. Food Microbiol 2017;62:289-297.

Gilbert JM, White DG, McDermott PF. The US national antimicrobial resistance monitoring system. Future Microbiol 2007; 2:493-500.

Glynn MK, Reddy V, Hutwagner L, Rabatsky-Ehr T, Shiferaw B, Vugia DJ, Segler S, Bender J, Barrett TJ, Angulo FJ; Emerging Infections Program FoodNet Working Group. Prior antimicrobial agent use increases the risk of sporadic infections with multidrug-resistant Salmonella enterica serotype Typhimurium: A FoodNet case-control study, 1996-1997. Clin Infect Dis 2004;38 Suppl 3:S227S236. 
Greene SK, Stuart AM, Medalla FM, Whichard JM, Hoekstra RM, Chiller TM. Distribution of multidrug-resistant human isolates of MDR-ACSSuT Salmonella Typhimurium and MDR-AmpC Salmonella Newport in the United States, 20032005. Foodborne Pathog Dis 2008;5:669-680.

Grinnell M, Provo G, Marsden-Haug N, Stigi KA, DeBess E, Kissler B, Crarey E, Pringle J, Grass J, Folster J, Williams I, Gieraltowski, Laufer AS. Outbreak of Salmonella Heidelberg infections linked to a single poultry producer, 2012-2013. MMWR Morb Mortal Wkly Rep 2013;62:553-556.

Gupta A, Fontana J, Crowe C, Bolstorff B, Stout A, Van Duyne S, Hoekstra MP, Whichard JM, Barrett TJ, Angulo FJ; National Antimicrobial Resistance Monitoring System PulseNet Working Group. Emergence of multidrug-resistant Salmonella enterica serotype Newport infections resistant to expanded-spectrum cephalosporins in the United States. J Infect Dis 2003;188:1707-1716.

Gupta A, Nelson JM, Barrett TJ, Tauxe RV, Rossiter SP, Friedman CR, Joyce KW, Smith KE, Jones TF, Hawkins MA, Shiferaw B, Beebe JL, Vugia DJ, Rabatsky-Ehr T, Benson JA, Root TP, Angulo FJ; NARMS Working Group. Antimicrobial resistance among Campylobacter strains, United States, 1997-2001. Emerg Infect Dis 2004;10:1102-1109.

Henao OL, Jones TF, Vugia DJ, Griffin PM; Foodborne Diseases Active Surveillance Network (FoodNet) Workgroup. Foodborne diseases active surveillance network-2 Decades of achievements, 1996-2015. Emerg Infect Dis 2015;21:1529-1536.

Howie RL, Folster JP, Bowen A, Barzilay EJ, Whichard JM. Reduced azithromycin susceptibility in Shigella sonnei, United States. Microb Drug Resist 2010;16:245-248.

Huang JY, Henao OL, Griffin PM, Vugia DJ, Cronquist AB, Hurd S, Tobin-D'Angelo M, Ryan P, Smith K, Lathrop S, Zansky S, Cieslak PR, Dunn J, Holt KG, Wolpert BJ, Patrick ME. Infection with pathogens transmitted commonly through food and the effect of increasing use of culture-independent diagnostic tests on surveillance-Foodborne Diseases Active Surveillance Network, 10 U.S. sites, 2012-2015. MMWR Morb Mort Wkly Rep 2016;65:368-371.

Iwamoto M, Huang JY, Cronquist AB, Medus C, Hurd S, Zansky S, Dunn J, Woron AM, Oosmanally N, Griffin PM, Besser J, Henao OL. Bacterial enteric infections detected by culture-independent diagnostic tests-FoodNet, United States, 2012-2014. MMWR Morb Mortal Wkly Rep 2015;64: 252-257.

Iwamoto M, Reynolds J, Karp BE, Tate H, Fedorka-Cray PJ, Plumblee J, Hoekstra RM, Whichard JM, Mahon BE. Ceftriaxone-resistant nontyphoidal Salmonella from humans, retail meats, and food-producing animals in the United States, 1996-2013. Foodborne Pathog Dis 2017;14:74-83.

Jackson CR, Fedorka-Cray PJ, Barrett JB, Hiott LM, Woodley TA. Prevalence of streptogramin resistance in enterococci from animals: Identification of vatD from animal sources in the USA. Int J Antimicrob Agents 2007;30:60-66.

Jackson CR, Fedorka-Cray PJ, Barrett JB, Hiott LM, Woodley TA. First report of $v a t B$ and $v g a B$ from Enterococcus gallinarum in the USA. Int J Antimicrob Agents 2008;31:175-176.

Jackson CR, Fedorka-Cray PJ, Barrett JB, Ladely SR. Highlevel aminoglycoside resistant enterococci isolated from swine. Epidemiol Infect 2005;133:367-371.

Kassenborg HD, Smith KE, Vugia DJ, Rabatsky-Ehr T, Bates MR, Carter MA, Dumas NB, Cassidy MP, Marano N, Tauxe RV, Angulo FJ. Fluoroquinolone-resistant Campylobacter infections: Eating poultry outside of the home and foreign travel are risk factors. Clin Infect Dis 2004;38:S279-S284.
Krueger AL, Greene SA, Barzilay EJ, Henao O, Vugia D, Hanna S, Meyer S, Smith K, Pecic G, Hoefer D, Griffin PM. Clinical outcomes of nalidixic acid, ceftriaxone, and multidrug-resistant nontyphoidal Salmonella infections compared with pansusceptible infections in FoodNet sites, 20062008. Foodborne Pathog Dis 2014;11:335-341.

Ladely SR, Meinersmann RJ, Englen MD, Fedorka-Cray PJ, Harrison MA. 23S rRNA gene mutations contributing to macrolide resistance in Campylobacter jejuni and Campylobacter coli. Foodborne Pathog Dis 2009;6:91-98.

Lammie SL, Hughes JM. Antimicrobial resistance, food safety, and One Health: The need for convergence. Annu Rev Food Sci Technol 2016;7:287-312.

Liu YY, Wang Y, Walsh TR, Yi LX, Zhang R, Spencer J, Doi Y, Tian G, Dong B, Huang X, Yu LF, Gu D, Ren H, Chen X, Lv L, He D, Zhou H, Liang Z, Liu JH, Shen J. Emergence of plasmid-mediated colistin resistance mechanism MCR-1 in animals and human beings in China: A microbiological and molecular biological study. Lancet Infect Dis 2016;16:161-168.

Lloyd DH. Reservoirs of antimicrobial resistance in pet animals. Clin Infect Dis 2007;45:S148-S152.

Marshall BM, Levy SB. Food animals and antimicrobials: Impacts on human health. Clin Microbiol Rev 2011;24:718-733.

McDermott PF, Bodeis SM, Aarestrup FM, Brown S, Traczewski M, Fedorka-Cray P, Wallace M, Critchley IA, Thornsberry C, Graff S, Flamm R, Beyer J, Shortridge D, Piddock LJ, Ricci V, Johnson MM, Jones RN, Reller B, Mirrett S, Aldrobi J, Rennie R, Brosnikoff C, Turnbull L, Stein G, Schooley S, Hanson RA, Walker RD. Development of a standardized susceptibility test for Campylobacter with quality-control ranges for ciprofloxacin, doxycycline, erythromycin, gentamicin, and meropenem. Microb Drug Resist 2004;10:124-131.

McDermott PF, Bodeis-Jones SM, Fritsche TR, Jones RN, Walker RD. Broth microdilution susceptibility testing of Campylobacter jejuni and the determination of quality control ranges for fourteen antimicrobial agents. J Clin Microbiol 2005;43:6136-6138.

McDermott PF, Tyson GH, Kabera C, Chen Y, Li C, Folster JP, Ayers SL, Lam C, Tate HP, Zhao S. The use of whole genome sequencing for detecting antimicrobial resistance in nontyphoidal Salmonella. Antimicrob Agents Chemother 2016;60:5515-5520.

Medalla F, Hoekstra RM, Whichard JM, Barzilay EJ, Chiller TM, Joyce K, Rickert R, Krueger A, Stuart A, Griffin PM. Increase in resistance to ceftriaxone and nonsusceptibility to ciprofloxacin and decrease in multidrug resistance among Salmonella strains, United States, 1996-2009. Foodborne Pathog Dis 2013;10:302-309.

Meinersmann RJ, Ladely SR, Bono JL, Plumblee JR, Hall MC, Genzlinger LL, Cook KL. Complete sequence of a colistin resistance gene ( $m c r-1)$-bearing isolate of Escherichia coli from the United States. Genome Announc 2016b;4:e01283-e01316.

Meinersmann RJ, Ladely SR, Plumblee JR, Cook KL, Thacker E. Prevalence of $m c r-1$ in US food-animal cecal contents. Antimicrob Agents Chemother 2017;61:e02244-e02316.

Meinersmann RJ, Ladely SR, Plumblee JR, Hall MC, Simpson SA, Ballard LL, Scheffler BE, Genzlinger LL, Cook KL. Complete genome sequence of a colistin resistance $m c r-1$ gene-bearing Escherichia coli strain from the United States. Genome Announc 2016a;4:e00898-e00916.

[NMFS] National Marine Fisheries Service. Fisheries of the United States, 2014. NOAA Current Fishery Statistics No. 2014. Silver Spring, MD: U.S. Department of Commerce, 2015. Available at: www.st.nmfs.noaa.gov/commercial-fisheries/fus/ fus14/index, accessed October 17, 2016. 
Nelson JM, Chiller TM, Powers JH, Angulo FJ. Fluoroquinoloneresistant Campylobacter species and the withdrawal of fluoroquinolones from use in poultry: A public health success story. Clin Infect Dis 2007;44:977-980.

Nelson JM, Smith KE, Vugia DJ, Rabatsky-Ehr T, Segler SD, Kassenborg HD, Zansky SM, Joyce K, Marano N, Hoekstra RM, Angulo FJ. Prolonged diarrhea due to ciprofloxacin-resistant Campylobacter infection. J Infect Dis 2004;190:1150-1157.

O'Donnell AT, Vieira AR, Huang JY, Whichard J, Cole D, Karp BE. Quinolone-resistant Salmonella enterica serotype Enteritidis infections associated with international travel. Clin Infect Dis 2014;59:e139-e141.

Routh JA, Pringle J, Mohr M, Bidol S, Arends K, AdamsCameron M, Hancock WT, Kissler B, Rickert R, Folster J, Tolar B, Bosch S, Barton Behravesh C, Williams IT, Gieraltowski L. Nationwide outbreak of multidrug-resistant Salmonella Heidelberg infections associated with ground turkey: United States, 2011. Epidemiol Infect 2015;143:3227-3234.

Sapkota A, Sapkota AR, Kucharski M, Burke J, McKenzie S, Walker P, Lawrence R. Aquaculture practices and potential human health risks: Current knowledge and future priorities. Environ Int 2008;34:1215-1226.

Schmidt JW, Agga GE, Bosilevac JM, Brichta-Harhay DM, Shackelford SD, Wang R, Wheeler TL, Arthur TM. Occurrence of antimicrobial-resistant Escherichia coli and Salmonella enterica in the beef cattle production and processing continuum. Appl Environ Microbiol 2015;81:713-725.

Sjölund-Karlsson M, Folster JP, Pecic G, Joyce K, Medalla F, Rickert R, Whichard JM. Emergence of plasmid-mediated quinolone resistance among non-Typhi Salmonella enterica isolates from humans in the United States. Antimicrob Agents Chemother 2009;53:2142-2144.

Skov R, Matuschek E, Sjölund-Karlsson M, Ahman J, Petersen A, Stegger M, Torpdahl M, Kahlmeter G. Development of a pefloxacin disk diffusion method for detection of fluoroquinolone-resistant Salmonella enterica. J Clin Microbiol 2015;53:3411-3417.

Smith KE, Besser JM, Hedberg CW, Leano FT, Bender JB, Wicklund $\mathrm{JH}$, Johnson BP, Moore KA, Osterholm MT; The Investigation Team. Quinolone-resistant Campylobacter jejuni infections in Minnesota, 1992-1998. N Engl J Med 1999;340:1525-1532.

Tyson GH, McDermott PF, Li C, Chen Y, Tadesse DA, Mukherjee S, Bodeis-Jones S, Kabera C, Gaines SA, Loneragan GH, Edrington TS, Torrence M, Harhay DM, Zhao S. WGS accurately predicts antimicrobial resistancein Escherichia coli. J Antimicrob Chemother 2015;70:2763-2769.

Varma JK, Greene KD, Ovitt J, Barrett TJ, Medalla F, Angulo FJ. Hospitalization and antimicrobial resistance in Salmonella outbreaks, 1984-2002. Emerg Infect Dis 2005b;11:943-946.

Varma JK, Marcus R, Stenzel SA, Hanna SS, Gettner S, Anderson BJ, Hayes T, Shiferaw B, Crume TL, Joyce K, Fullerton KE, Voetsch AC, Angulo FJ. Highly resistant Salmonella NewportMDRAmpC transmitted through the domestic US food supply: A FoodNet case-control study of sporadic Salmonella Newport infections, 2002-2003. J Infect Dis 2006;194:222-230.

Varma JK, Molbak K, Barrett TJ, Beebe JL, Jones TF, Rabatsky-Ehr T, Smith KE, Vugia DJ, Chang HG, Angulo FJ. Antimicrobial-resistant nontyphoidal Salmonella is associated with excess bloodstream infections and hospitalizations. J Infect Dis 2005a;191:554-561.

Vieira AR, Grass J, Fedorka-Cray PJ, Plumblee JR, Tate H, Cole DJ. Attribution of Salmonella enterica serotype Hadar infections using antimicrobial resistance data from two points in the food supply system. Epidemiol Infect 2016;144:1983-1990.
Webb HE, Bugarel M, den Bakker HC, Nightingale KK, Granier SA, Scott HM, Loneragan GH. Carbapenem-resistant bacteria recovered from faeces of dairy cattle in the High Plains region of the USA. PLoS One 2016;11:e0147363.

Whichard JM, Gay K, Stevenson JE, Joyce KJ, Cooper KL, Omondi M, Medalla F, Jacoby GA, Barrett TJ. Human Salmonella and concurrent decreased susceptibility to quinolones and extended-spectrum cephalosporins. Emerg Infect Dis 2007;13:1681-1688.

White House. National Strategy for Combating AntibioticResistant Bacteria. 2014a. Available at: www.whitehouse. gov/sites/default/files/docs/carb_national_strategy.pdf, accessed September 2, 2016.

White House. Executive Order-Combating Antibiotic-Resistant Bacteria. 2014b. Available at: www.whitehouse.gov/the-pressoffice/2014/09/18/executive-order-combating-antibiotic-resistantbacteria, accessed September 2, 2016.

White House. National Action Plan for Combating AntibioticResistant Bacteria. 2015. Available at: www.whitehouse.gov/ sites/default/files/docs/national_action_plan_for_combating_ antibotic-resistant_bacteria.pdf, accessed September 2, 2016.

[WHO] World Health Organization. The Evolving Threat of Antimicrobial Resistance: Options for Action. 2012. Available at: www.who.int/patientsafety/implementation/amr/publication/ en/, accessed September 2, 2016.

WHO. Integrated Surveillance of Antimicrobial Resistance: Guidance from a WHO Advisory Group. 2013. Available at: www.who.int/foodsafety/publications/agisar_guidance/en/, accessed September 2, 2016.

WHO. Antimicrobial Resistance: Global Report on Surveillance. 2014. Available at: www.who.int/drugresistance/documents/ surveillancereport/en/, accessed September 3, 2016.

WHO. Antibiotic Resistance Fact Sheet. 2015. Available at: www.who.int/mediacentre/factsheets/antibiotic-resistance/en/, accessed September 2, 2016.

WHO/FAO/OIE. WHO, FAO, and OIE Unite in the Fight Against Antimicrobial Resistance. 2015. Available at: www .oie.int/fileadmin/Home/eng/Media_Center/docs/pdf/FAO_ OIE_WHO_AMRfactsheet.pdf, accessed September 2, 2016. Zhao S, Mukherjee S, Chen Y, Li C, Young S, Warren M, Abbott J, Friedman S, Kabera C, Karlsson M, McDermott PF. Novel gentamicin resistance genes in Campylobacter isolated from humans and retail meats in the USA. J Antimicrob Chemother 2015a;70:1314-1321.

Zhao S, Tyson GH, Chen Y, Li C, Mukherjee S, Young S, Lam C, Folster JP, Whichard JM, McDermott PF. Whole genome sequencing analysis accurately predicts antimicrobial resistance phenotypes in Campylobacter. Appl Environ Microbiol 2015b;82:459-466.

Zhao S, White DG, McDermott PF, Friedman S, English L, Ayers S, Meng J, Maurer JJ, Holland R, Walker RD. Identification and expression of cephamycinase bla CMY $_{\mathrm{C}}$ genes in Escherichia coli and Salmonella isolates from food animals and ground meat. Antimicrob Agents Chemother 2001;45:3647-3650.

Address correspondence to: Beth E. Karp, DVM, MPH, DACVPM Division of Foodborne, Waterborne, and Environmental Diseases Centers for Disease Control and Prevention 1600 Clifton Road NE, MS-C09 Atlanta, GA 30329

E-mail: bkarp@cdc.gov 